Uluslararası Sosyal Bilgilerde Yeni Yaklaşımlar Dergisi,2020, 4(2), 309-321

International Journal of New Approaches in Social Studies, 2020, 4(2), 309-321

\title{
Okul Öncesi Öğretmen Adaylarının Sanat Eğitimi ve Görsel Sanatlar Dersine İlişkin Tutumlarının incelenmesi
}

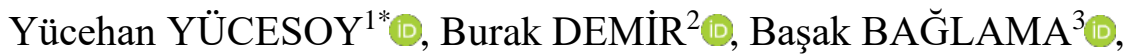 \\ Ümit POLAT ${ }^{4}$ \& Behçet ÖZNACAR ${ }^{5}$ (D)
}

Gönderilme Tarihi: 28 Eylül $2020 \quad$ Kabul Tarihi: 11 Aralık 2020

DOI: $10.38015 /$ sbyy. 801298

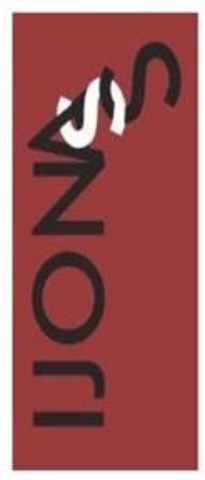

\begin{abstract}
$\ddot{O} z:$
Ögretmen adaylarının sanatsal farkındalıklarının geliştirilmesi ve mesleki yaşamlarında sanata karşı olan duyarlılıklarının arttırılması için sınıflarında nitelikli sanatsal deneyimler sağlamaları, sanatı hem bir amaç hem de bir araç olarak kullanabilmeleri önemlidir. Bu araştırma ile Okul Öncesi Öğretmen Adaylarının Sanat Eğitimi ve Görsel Sanatlar Dersine Illişkin Tutumlarının incelenmesi amaçlanmıştır. Araştırmanın çalışma grubunu ,2019-2020 ĕgitim öğretim yılında üniversitelerde okumakta olan yaşları gönüllülük esasına yönelik katılım gösteren 55 Okul Öncesi Öğretmeni adayı oluşturmaktadır. Araştırma kapsamında okul öncesi öğretmeni adaylarının Görsel Sanatlar Dersine ve Sanat eğitimine yönelik tutumlarının belirlenmesi için Sanat Ĕ̈itimine Yönelik Tutum ve Görsel Sanatlar Dersine Yönelik Tutum ölçeği kullanılmıştır. Veriler SPSS 17 istatistik programı ile analiz edilmiş ve güvenirlik geçerlilik testleri yapılmıştır. Verilerin analizlerinde Pearson Korelasyon dan faydalanılmış Bulgular frekans (n) dă̆llımı, ortalama ve standart sapmalardan oluşan özet tablolarla sunulmuştur. Yapılan tüm analizlerde anlam düzeyi $\% 5(p=0,05)$ olarak alınmıştır. Araştırmanın sonucunda; okul öncesi öğretmenlerinin sanat kavramını kapsayan tanımları kullanmaya çalıştıkları; çeşitli sanat dallarını ve bu sanat dallarından en çok görsel sanat dallarına ait alt dalları bildikleri; öğretmenlerin çoğunluğunun bir sanat dalı ile uğraştıklarl ya da ŭgraşmak istedikleri; uğraşma ve uğraşmak isteme durumlarının çeşitli nedenlere bağlı olduğu bulunmuştur. Ayrıca ögretmenlerin tamamının çeşitli nedenlere bağlı olarak sanatla ilgilenilmesi gerektiği yönünde görüş bildirdikleri tespit edilmiştir.
\end{abstract}

Anahtar Kelimeler: Okul öncesi öğretmenliği, görsel sanatlar sanat eğitimi, sanat eğitim.

\begin{abstract}
:
It is important for teacher candidates to provide qualified artistic experiences in their classrooms and to be able to use art both as a goal and as a tool in order to improve their artistic awareness and increase their sensitivity towards art in their professional lives. With this research, it is aimed to examine Preschool Teacher Candidates' Attitudes towards Art Education and Visual Arts Lesson. The study group of the research consists of 55 Preschool Teacher candidates who are studying at universities in the 2019-2020 academic year and who participate on a voluntary basis. Within the scope of the
\end{abstract}

\footnotetext{
${ }^{1}$ Yakın Doğu Üniversitesi, Kuzey Kıbrıs Türk Cumhuriyeti. Orcid ID: 0000-0001-8171-3130

${ }^{2}$ Yakın Doğu Üniversitesi, Kuzey Kıbrıs Türk Cumhuriyeti. Orcid ID: 0000-0001-5666-359X

${ }^{3}$ Yakın Doğu Üniversitesi, Kuzey Kıbrıs Türk Cumhuriyeti. Orcid ID: 0000-0002-5484-4618

${ }^{4} \mathrm{Niğde} \mathrm{Ömer} \mathrm{Halis} \mathrm{Demir} \mathrm{Üniversitesi,} \mathrm{Türkiye.} \mathrm{Orcid} \mathrm{ID:} \mathrm{0000-0002-0601-9074}$

${ }^{5}$ Yakın Doğu Üniversitesi, Kuzey Kıbrıs Türk Cumhuriyeti. Orcid ID: 0000-0002-6738-645X

*Sorumlu Yazar (Corresponding Author): yucehan.yucesoy@ neu.edu.tr
} 
Y. YÜCESOY, B. DEMIR, Okul Öncesi Öğretmen Adaylarının Sanat Eğitimi ve Görsel

B. BA $\breve{G} L A M A, \ddot{U}$. POLAT Sanatlar Dersine İlişkin Tutumlarının incelenmesi

\& B. ÖZNACAR

research, in order to determine the attitudes of pre-school teacher candidates towards Visual Arts Lesson and Art Education, Attitude Towards Art Education and Attitude Towards Visual Arts Lesson scale was used. The data were analyzed with SPSS 17 statistical program and validity tests were conducted. Pearson Correlation was used in the analysis of the data. Results were presented in summary tables consisting of frequency $(n)$ distribution, mean and standard deviation. The significance level was taken as 5\% $(p=0.05)$ in all analyzes. As a result of the research; preschool teachers try to use definitions that cover the concept of art; they know various branches of art and the sub-branches of these branches of art, mostly visual arts; that the majority of teachers are engaged in or want to deal with a branch of art; It has been found that striving and willingness to engage are due to various reasons. In addition, it was determined that all of the teachers expressed their opinion that art should be taken care of due to various reasons.

Keywords: Preschool teaching, visual arts art education, art education.

\section{GíRIŞ}

Eğitim kavramının temelinde öğrenme öğretme süreci içerisinde en değerli yapı taşlarından biri öğretmendir. Alan yazın içerisinde öğretmenlik üzerine birden fazla tanımların yer aldığı görülmektedir. Öğretmen eğitim sektörü içerisinde yer alan öğrencilere istenilen kazanımların yerleşmesini hedef edinen ve bunu gerçekleştirebildiği oranda eğitim kalitesinin yüksek seviyede ve donanımlı olduğunu belirten kişi olduğu söylenilebilir. Türkiye Cumhuriyeti'nde eğitim ve öğretime yönelik tartışmalarda farklı görüşler olsa bile eğitimde ve öğrenme öğretme ortamı içerisinde temel öğenin öğretmen olduğuna dair ortak bir kanı bulunmaktadır. Toplum içerisinde birbirinden farklı tanımlarla karşılaş1lsa bile öğretmen faktörünün eğitimin temel yapı taşı olduğuna dair fikir birliği bulunmaktadır (Polat,2015). Bunların yanında öğretmen, gelecek kuşakların bilişsel, duyuşsal gelişimi ve yaşama biçimini yönlendiren, öğrencilerin ders kitapları ve öğretim materyalleri kullanarak öğrencileri hazırlayarak onların kendilerine ve topluma karşı tutumlarını şekillendiren, iletişim, araştırma ve yaratıcılık becerilerinin gelişimini etkileyen bir kişidir. Bir ülkenin de varlık nedenidir (Demir, 2020).

Özellikle okul öncesi dönemi, çocukların bedensel, zihinsel, duygusal ve sosyal olarak gelişimlerinin ve öğrenmelerinin en üst düzeyde olduğu dönem olup, aynı zamanda çocuğun kişilik, yetenek, yaratıcılığın ve hayal gücünün şekillendiği dönemdir. İşte bu dönemde öğretmenlere çok büyük bir görev düşmektedir.

Okul öncesi dönemde bireylere verilecek olan eğitimin kalitesi bireyin yetişkinlik evresi için son derece etkilidir. Sanat eğitimi ile birlikte bireyler kendilerini daha iyi anlamakla birlikte sanatın öğreticiliği ile günlük yaşamlarına yeni tecrübeler katarlar. Öğretmenlerin bireylere verecekleri bu eğitimde açı net ve geniş bir şekilde gerçekleştirmeleri içerisinde bulunduğumuz yüzyılın yadsınamaz gerçeklerinden birdir. Sanat varoluşun ilk anından itibaren bireyin kendini net bir şekilde ifade etmesine yardımcı olan güncel ve çağdaşlaşmanın işlevlerini en etkin bir şekilde yerine getiren bir olgudur. $\mathrm{Bu}$ özellikleriyle sanatın insan yaşamında üstlendiği görev bireylere verilen sanat eğitiminin ne denli önemli olduğunu gözler önüne sermektedir. Sanat eğitimi, yaratıcılığ ve eleştirel düşünebilen bir bireyi yetiştirmek için İnsanın doğayı yaşamı daha iyi algılaması ile birlikte bireysel fikirlerinin sanatsal yollarla aktarılmasını amaçlar (MEB, 2006). Okul öncesi eğitim kurumları içerisinde yer alan öğrenme öğretme sürecinde bazı öğretmenlerin belli çerçeveler içerisinden çıkmayarak eğitimi gerçekleştirdiği bunun 1 şı ğında ise öğrencilerin yaratıcı düşünme becerilerinin daha az kullanıldığı söylenilebilir. Öğretmenlerin etkinliklerde belli normları kullanmaları ve hangi malzemelerin yer alıp almayacaklarına etkinlik süresinin ne kadar olacağına dair karar vermeleri ögretmenler için daha kolay bir yol olması bireylerin kendilerini ifade etmeleri ve yaratıcılıkların gelişmesinde sorun yaşamalarını sağlamaktadır. Okul öncesi döneminde örenme 
ortamı içerisinde bağımsız karar veren bireyler yetiştirmek temel amaç olmakla birlikte bu amaç doğrultusunda bireylere önceden kurgulanmış içerikler verilmesi, gerek okul öncesi öğretmenleri gerekse kurumların yöneticilerine kadar olumlu örgüt iklimin oluşmasını engellemekte ve bağımsız bireylerin yetişmesinin önünü kesmektedir (Yücesoy, Demir, Bağlama, Baştaş \& Öznacar, 2020; Székely, 2001).Sanat eğitimi sürecinde kullanılan materyaller son derece etkili ve önem arz etmektedir Öğrenme ortamında özellikle günümüz teknolojinin gelişmesi ile birlikte infografiklerin, artırılmış gerçekliklerin kullanımının artması ile sanat eğitimi içerisinde de teknolojinin yer alabileceği hatta teknolojinin desteği ile birlikte sosyal medyada dahil olmak üzere bir çok mecranın yer alabileceği materyaller kullanılabilir ve öğrencilerin yaratıcılıklarında artmasını sağlayan tekniklerle birlikte sanat eğitimi için birey seviyesine yönelik materyallerin kullanılması açısından sınırlandırmaların daha rahat bir şekilde yapılacağı söylenilebilir (Bicen ve Demir, 2020; Faraday, 1990; Nacak, Baglama, Demir, 2020). Okul öncesi dönemde yer alan bireyler yeni şeyleri keşfetmek ve bu keşfettikleri olguları çeşitli malzemelerde sanatsal çalışmalar haline getirmek için son derece heveslidirler (California Department of Education, 2004). Okul öncesi dönemde sanatsal eğitim için kullanılan araç ve gereçlerin çoğuna sanatsal materyal adı verilmektedir. Bu materyaller uygun bir biçimde kullanıldıkları zaman bireyleri yaratıcı düşünmeye sürükleyen malzemeler haline gelmektedirler (Drew, 1995). Okul öncesi dönemi geçen ve yetişkinlik dönemine giren bireylerin daha nadir kullandıkları bu materyaller okul öncesi bireyler için son derece yaratıcı bir şekilde bir araya getirilen sanat eserlerine dönüşebilirler (Székely, 2001).

Öğrenciler çeşitli sanatsal materyaller kullanarak meydana getirdikleri çalışmalarda iki veya üç boyutlu araçlar oluşturarak çizgi, renk, şekil ve dokuya yönelik tecrübeler kazanmış olurlar (California Department of Education, 2004). Geri dönüşüm ile elde edilmiş olan malzemelerle elde edilen çalışmalar ise bireyde şekil ve denge gibi olguların meydana gelmesine son derecede etkilidir. (Erdemir \& Kandır, 2002). Diğer bir deyişle bireylerin kullandıkları materyal çeşitliliği kişilerde farklı anlamlar ve kazanımların meydana gelmesinde son derece etkili olduğu sonucuna ulaşılmakla birlikte bir o kadar da yaratıcılıklarının artmasını sağlayacaktır (Eckhoff \& Spearman, 2009; Gandini \& Kaminsky, 2005).

\section{Araştırmanın Amacı}

$\mathrm{Bu}$ araştırmanın amacı, okulöncesi eğitim alanında öğrenim gören öğretmen adaylarının Sanat Eğitimi ve Görsel Sanatlar dersine ilişkin görüşlerinin belirlenmesidir.

\section{Sanat Ĕ̈itimi Dersi}

Günümüzde Sanat eğitimi ile birlikte kendi yaratıcılıklarını sanat vasıtasıyla ifade eden içerisinde yer aldığı kültürü tanıyan ve daha sonraki nesillere aktarma sorumluluğuna sahip bireylerin yetiştirilmesi temel amaç olarak ele alınır. Sanat eğitimi dersinin bu amacı yerine getirebilmesi için eğitim sürecinin her anında, her kademesi içerisinde seviyelere uygun öğretim programlarının bulunması gerekmektedir (Nacak \& Yucesoy, 2020).

Sanat eğitimini tarih, estetik, eleştiri ve uygulama boyutlarının hepsini içine alan bir bütün olarak düşünülebilir. Sanat eğitimi sürecinde öğrenciler teorik olarak derslere başlamalı ders hakkındaki beklentileri ve kazanımları için fikirleri alınmalıdır. Teorik başlangıç sonrasındaki uygulama boyutunda bile kullanılacak materyaller hakkında gerekli teorik bilgiler verilmeli soru cevap ve beyin firtınası yapılarak fikirleri alındıktan sonra uygulama boyutuna geçilmelidir. 
Y. YÜCESOY, B. DEMIR, Okul Öncesi Öğretmen Adaylarının Sanat Eğitimi ve Görsel

B. BA $\breve{G} L A M A, \ddot{U}$. POLAT Sanatlar Dersine İlişkin Tutumlarının incelenmesi

\& B. ÖZNACAR

\section{Görsel Sanatlar Ĕgitimi Dersi}

Görsel Sanatlar Eğitimi bireylerin öğrenme öğretme süreci içerisindeki gün aşırı elde ettikleri kazanımlar arasında mantıklı bir ilişki kurmasını temel alan son derece geniş bir eğitim şeklidir. (Alakuş \& Mercin, 2009; Başbuğ \& Başbuğ, 2016). Günümüz eğitim sürecinde uygulanan görsel sanatlar eğitimi programları incelendiğince daha önce yer alan ve kullanılmakta olan programlarından daha farklı bir yapıda olduğu sonucuna ulaşılmıştır. Görsel sanatlar dersi programları oluşturulma aşamasında ilk önce sadece resim boyutunu ele alan Resim-İș dersini zenginleştirerek heykel, seramik gibi sanat alanlarını ele alan ve içeriği genişletilmiş bir şekilde Görsel Sanatlar eğitimi dersi olarak programlarda günümüzde yer almıştır (Ertürk, 2013). Görsel sanatlar dersi öğrenme sürecinde bireylerinin yaratıcılıklarını kullanmasını sağlamakla birlikte, yeni şeyler üretmeye iten ve bu süreçler gerçekleşirken kişilerin eğlenmesini ve eleştirel düşünmeye iten bir ders olmuştur (Özsoy, 2006). Öğrenciler açısından ilgi uyandıran bir dersin programı içinde de bazı önemli etkinlikler yaparak, dersi daha anlaşılabilir kılmak mümkün ve olasıdır. Görsel sanatlar dersinde birey ya da öğrenciler sadece rahatlama ve eğlence aracı olarak görmekten çıkararak, daha verimli ve bilimsel yönünü sorgulayan, araştıran bir konuma getirmek gereklidir. Böylece gelişim ve süreç sonunda birey, sanat formlarını ve ilkelerini daha hızlı şekilde yakalamaya yönelir. Dersin içeriğine bilgisayar teknolojisinin de dahil edilerek farklı, özgün çizgilerle birlikte renklerin anlam kazandırılacağ tamamen aklın üretebileceği ş̧ekiller ve konular elde edilmelidir (Başbuğ \& Başbuğ, 2016). Bu anlamda, dersin amacı çağa uygun ve günümüz teknolojilerinin uzağında kalmayacaktır. (Yücesoy, Bağlama \& Tüzel, 2020).

Görsel sanatlar dersi içerisinde resim dersinin klasik ve geleneksel boyutundan uzaklaşılmış, öğretmende öğrencinin yanında sadece bir danışman olarak değil aktif bir şekilde görev alan bir eğitici haline gelmiştir. Buna paralel olarak öğretmenlerin kendilerini geliştirerek hizmet içi eğitimlere katılması ve daha zengin materyaller kullanarak dersi etkili ve anlaşılır bir hale getirmelidir. Buradan hareketle bu araştırmanın genel amacı Okul öncesi öğretmen adaylarının Görsel sanatlar dersine yönelik tutumları ve sanat eğitimine yönelik tutumlarının incelenmesi amaçlanmaktadır. Bu genel amaçtan hareketle öğretmen adaylarının kullanılan ölçeklere verdikleri cevapların ortalama oranları karşılaştırarak en fazla ortalama ve en az hangi dereceleri belirleyerek cevaplandırma yaptıkları ve bu cevaplardan hareketle bu iki disipline yönelik tutumlarının karşılaştırılması amaçlanmıştır.

\section{YÖNTEM}

\section{Araştırmanın Modeli}

Çalışma nicel araştırma türlerinden tarama yöntemi kullanılarak yapılmıştır. Tarama yönteminin kullanıldığı araştırmalar; bir olay, olgu veya konuya nitelik bireylerin görüşleri, düşünceleri veya tutumları hakkında özelliklerinin ortaya çıkarıldığı ve yorumlandığ çalışmalardır. (Büyüköztürk, Çakmak, Akgün, Karadeniz ve Demirel, 2009).

\section{Örneklem/Çalışma Grubu/Katılımcılar}

Araştırmanın çalışma grubunu 2019-2020 eğitim öğretim yılında Kuzey Kıbrıs Türk Cumhuriyeti'nde Lefkoşa ili içerisindeki üniversitelerde okumakta olan yaşları 18-27 arası gönüllülük esasına yönelik katılım gösteren 3-4. sınıf olan 43 Kadın ve 12 erkek 55 okul öncesi öğretmeni adayı oluşturmaktadır. 
Y. YÜCESOY, B. DEMIR, Okul Öncesi Öğretmen Adaylarının Sanat Eğitimi ve Görsel

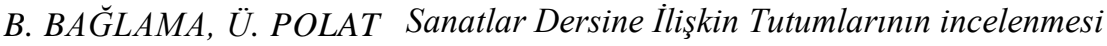

\& B. ÖZNACAR

\section{Veri Toplama Araçları/Veri Toplama Yöntemleri /Veri Toplama Teknikleri}

Araştırma kapsamında okul öncesi öğretmeni adaylarının Görsel Sanatlar Dersine ve Sanat eğitimine yönelik tutumlarının belirlenmesi için Aykanat (2018) tarafından geliştirilen geçerliliği düşük faktör yükü 0.15 ve en yüksek 0.925 olarak belirlenen güvenirliği ise sanattan hoşlanma ve sanatın katkısı için 0.94; sanata yönelik olumsuz tutumlar için 0.95; iletişim artırıcı rolü için 0.89 ve önemlilik rolü için 0.81 Cronbach Alpha değeri hesaplanmıştır. Bu sonuçlara göre ölçeğin iç tutarlılığı ve 59 güvenirliği son derece yüksek olarak belirlenen 5li likert tipine sahip olan Sanat Eğitimine Yönelik Tutum ölçeği Aslantaş (2014) tarafından geliştirilen RMSEA: 0.079 olarak geçerliliği hesaplanan güvenirliği ise 28 maddenin toplamı için iç tutarlılık katsayısı (Cronbach alpha) 0.923 olarak belirlenen Görsel Sanatlar Dersine Yönelik Tutum ölçeği kullanılmıştır. Ölçek doğrultusunda öğretmen adaylarının sorulara verilen cevaplarının ölçeklerin maddelerine yönelik genel cevaplarının oranına ulaşabilmek amacı ile verilen yanıtların ortalaması alınıp tablolaştırılarak yorumlanmıştır.

\section{Verilerin Analizi}

Çalışmada elde edilen veriler SPSS 17 istatistik programı ile analiz edilmiş. Verilerin analizlerinde Pearson Korelasyon dan faydalanılmış Bulgular frekans (n) dağılımı, ortalama ve standart sapmalardan oluşan özet tablolarla sunulmuştur. Görsel Sanatlar Dersine yönelik Tutum ölçeğine verilen cevaplar analiz edilirken likert değerlerine göre Hiç Katılmıyorum "1", Katılmiyorum "2", Katıliyorum "3", Tamamen Katıliyorum"4" şekline oran verilirken Sanat Eğitimine Yönelik Tutum ölçeğinde ise Kesinlikle Katıllyorum "1", Katılıyorum "2", Kararsızım "3", Katılıyorum "4", Kesinlikle Katılıyorumise "5" şeklinde oranlanmıştır. Yapılan tüm analizlerde anlam düzeyi \%5 (p=0.05) olarak alınmıştır. 
Y. YÜCESOY, B. DEMIR, Okul Öncesi Öğretmen Adaylarının Sanat Eğitimi ve Görsel

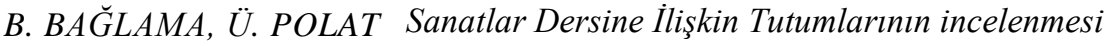

\& B. ÖZNACAR

\section{BULGULAR, YORUM VE TARTIŞMA}

Tablo 1. Okul Öncesi Öğretmen Adaylarının Görsel Sanatlar Dersine Yönelik Tutum

\begin{tabular}{|c|c|c|c|c|}
\hline & $\mathbf{N}$ & Min & Max & $\overline{\mathbf{X}}$ \\
\hline Görsel Sanatlar dersinin süresinin daha uzun olmasını isterim & 55 & 1,00 & 4,00 & 1,8 \\
\hline Görsel Sanatlar dersinde sıkılırım & 55 & 1,00 & 4,00 & 2,1 \\
\hline Görsel Sanatlar dersi benim için zordur & 55 & 1,00 & 4,00 & 2,0 \\
\hline Görsel Sanatlar dersinde kendimi mutsuz hissederim. & 55 & 1,00 & 4,00 & 2,2 \\
\hline Görsel Sanatlar dersinin benim için önemi yoktur. & 55 & 1,00 & 4,00 & 1,9 \\
\hline $\begin{array}{l}\text { İleride Görsel Sanatlar ile ilgili (ressam, heykeltıraş, grafiker gibi) bir meslek } \\
\text { seçmek isterim. }\end{array}$ & 55 & 1,00 & 4,00 & 2,3 \\
\hline Görsel Sanatlar dersi eğlenceli bir derstir. & 55 & 1,00 & 4,00 & 2,1 \\
\hline Görsel Sanatlar dersinde bulunmaktan mutlu olurum. & 55 & 1,00 & 4,00 & 2,3 \\
\hline $\begin{array}{l}\text { Görsel Sanatlar dersi ile ilgili bilgilerimi artırmak için ders dışında bir çaba } \\
\text { göstermem }\end{array}$ & 55 & 1,00 & 4,00 & 2,4 \\
\hline Görsel Sanatlar dersini kolay anlarım. & 55 & 1,00 & 4,00 & 2,2 \\
\hline $\begin{array}{l}\text { Derslerimin içinde en çok "Görsel Sanatlar" dersi etkinlikleri yaparken mutlu } \\
\text { olurum. }\end{array}$ & 55 & 1,00 & 4,00 & 2,3 \\
\hline Görsel Sanatlar dersine ayrılan süresinin daha az olmasını isterim & 55 & 1,00 & 4,00 & 2,1 \\
\hline Görsel Sanatlar dersi olduğu gün okula daha mutlu giderim & 55 & 1,00 & 4,00 & 2,1 \\
\hline Görsel Sanatlar dersinde yaptığım etkinliklerle ilgili konuşmaktan mutlu olurum & 55 & 1,00 & 5,00 & 2,2 \\
\hline Görsel Sanatlar dersi olduğu gün okula gitmek istemem. & 55 & 1,00 & 4,00 & 2,0 \\
\hline Diğer derslerle karşılaştırdığımda “Görsel Sanatlar” dersinde daha mutlu olurum. & 55 & 1,00 & 4,00 & 2,2 \\
\hline Görsel Sanatlar dersinde öğrendiğim konularla ilgili ders dışında etkinlik yapmam & 55 & 1,00 & 4,00 & 1,9 \\
\hline Görsel Sanatlar dersinde etkinlikleri yapmakta zorlanırım & 55 & 1,00 & 4,00 & 2,3 \\
\hline Görsel Sanatlar dersine çalışırken sıkılırım & 55 & 1,00 & 5,00 & 2,2 \\
\hline Görsel Sanatlar dersinde yeni konular öğrenmek beni heyecanlandırır & 55 & 1,00 & 4,00 & 1,9 \\
\hline Görsel Sanatlar dersi ödevlerini keyifle yaparım & 55 & 1,00 & 4,00 & 2,0 \\
\hline Görsel Sanatlar dersinde yapılan etkinlikler ilgimi çekmez & 55 & 1,00 & 4,00 & 1,9 \\
\hline Görsel Sanatlar dersinde kendimi rahat hissederim & 55 & 1,00 & 4,00 & 2,0 \\
\hline Görsel Sanatlar dersindeki etkinlikler beni dinlendirir & 55 & 1,00 & 4,00 & 2,1 \\
\hline Görsel Sanatlar dersi çok sevdiğim dersler arasındadır & 55 & 1,00 & 4,00 & 2,0 \\
\hline Görsel Sanatlar dersi ilgi duyduğum bir ders değildir & 55 & 1,00 & 4,00 & 1,9 \\
\hline Boş zamanlarımda resim yapmaktan hoşlanırım & 55 & 1,00 & 4,00 & 2,0 \\
\hline $\begin{array}{l}\text { Görsel Sanatlar dersinde öğrendiğim konularla ilgili ders dışında etkinlikler } \\
\text { yaparım }\end{array}$ & 55 & 1,00 & 4,00 & 1,9 \\
\hline Valid N (listwise) & 55 & & & 1,9 \\
\hline
\end{tabular}

Tablo 1'e bakıldığında görsel sanatlar dersine yönelik tutum ölçeğine verilen cevapları ve bu cevapların ortalaması görülmektedir bundan yola çıkarak verilen cevaplar değerlendirildiğinde ve ortalamalar göz önünde bulundurulduğunda en fazla verilen cevap oranın 1,9 ve 2,0 olduğu görülmektedir bu oranların ölçekteki karşılığı ise "'hiç katılmıyorum' ve "katılmıyorum", seçeneğinin yoğunlukla işaretlendiği söylenebilir ölçeğe verilen cevaplar doğrultusunda ise ortalama olarak verilen cevapların oranı ise 2,1 ve 2,2 oranlarının yoğunlukta olduğu görülmektedir bu oranların yer aldığı seçenek ise ölçek üzerinde ' katılmıyorum' seçeneğine denk gelmektedir. Ölçek üzerinde en az cevap verilen oranlar ise 2,4 ve 2,3 tür bu seçenekler ise ölçek üzerinde tekrar ' "katılmıyorum"' seçeneğini belirtmektedir. 
Y. YÜCESOY, B. DEMIR, Okul Öncesi Öğretmen Adaylarının Sanat Eğitimi ve Görsel

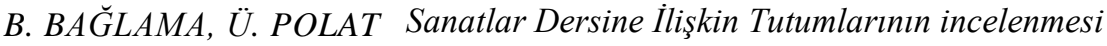

\& B. ÖZNACAR

Tablo 2. Okul Öncesi Öğretmen Adaylarının Sanat Eğitimine Yönelik Tutumları

\begin{tabular}{|c|c|c|c|c|}
\hline & $\mathbf{N}$ & Min & Max & $\overline{\mathbf{X}}$ \\
\hline Sanat eğitiminin bana sanatsal anlamda seçicilik kazandırdığını düşünüyorum & 55 & 1,00 & 5,00 & 1,8 \\
\hline Sanat eğitimine ayrılan ders saatlerinin diğer derslere oranla daha fazla olmasını & 55 & 1,00 & 5,00 & 2,1 \\
\hline
\end{tabular}

isterim

Yaptığım çalışmaların okul dışı etkinliklerde de kullanılmasını isterim

$\begin{array}{llll}55 & 1,00 & 5,00 & 2,0 \\ 55 & 1,00 & 5,00 & 2,1 \\ 55 & 1,00 & 5,00 & 2,0\end{array}$

Bölümümüz eğitimcilerinin kendi çalışmaları ile bize örnek olmalarını oldukça önemli görüyorum

Alanımda yaşadığım bazı başarısızlıkların sebebinin eğitimcilerimize bağlı olduğunu düşünüyorum

Sanatla ilgili bir bölümü seçtiğim için çok memnunum

$\mathrm{Bu}$ alanı sanata yönelik yeteneğimi göz önünde tutarak seçtim

$\mathrm{Bu}$ alanı sanat eğitiminin gerekliliğine inandığım için seçtim

Toplumda sanat eğitimine yeterince değer verilmediğini düşünüyorum

Sanat eğitimcisinin toplumdaki statüsünün düşük olduğuna inanıorum

Sanat eğitimi sürecinin entelektüel bir boyuta sahip olduğuna inanıyorum

Sanat eğitimini bir meslek kazandırma süreci değil bir yaşam tarzı olarak görüyorum

Sanatçının ve sanat eğitimcisinin sorumluluğunun diğer mesleklerden daha fazla olduğunu düşünüyorum

Sanatsal becerilerin mezuniyet sonrası süreçte de geliştirilebileceğini düşünüyorum

Boş zamanlarımda da sanatsal çalışmalar yapmaktan keyif alırım

Çalışma ortamlarımızda fiziksel iyileştirmeler yapılması gerektiğini düşünüyorum

İleride sanat eğitimine önemli katkılar sağlayabileceğime inanıyorum

Sanat eğitiminde teknolojiden faydalanılmasını gerekli görüyorum

Sanat eğitiminde farklı tekniklerin kullanılmasının sanatsal becerileri geliştireceğini düşünüyorum

Sanat eğitiminde kullanılan araç ve gereçlerin pahalı olması gerekmez

$55 \quad 1,00$

$5,00 \quad 2,3$

$55 \quad 1,00 \quad 5,00 \quad 2,4$

$55 \quad 1,00 \quad 5,00 \quad 2,4$

$55 \quad 1,00 \quad 5,00 \quad 2,4$

$55 \quad 1,00 \quad 5,00 \quad 2,1$

$55 \quad 1,00 \quad 5,00 \quad 2,2$

$55 \quad 1,00 \quad 5,00 \quad 2,0$

$55 \quad 1,00 \quad 5,00 \quad 2,0$

$55 \quad 1,00 \quad 5,00 \quad 2,0$

$55 \quad 1,00 \quad 4,00 \quad 1,8$

$55 \quad 1,00 \quad 4,00 \quad 2,0$

$55 \quad 1,00 \quad 5,00 \quad 1,9$

$55 \quad 1,00 \quad 4,00 \quad 2,0$

$55 \quad 1,00 \quad 5,00 \quad 1,9$

$55 \quad 1,00 \quad 4,00 \quad 2,1$

Sanat eğitiminde grup çalışmaları yapmayı faydalı buluyorum

$55 \quad 1,00 \quad 5,00 \quad 2,0$

$55 \quad 1,00 \quad 5,00 \quad 2,0$

Sanat eğitimi yoluyla farklı ülkelerin sanatlarını tanımaktan zevk alıyorum

Sanat eğitimi sürecindeki tüm derslere her seferinde istekli girerim

Sanat eğitimi sürecinde yapılan tüm çalışmaların zevkli olduğunu düşünüyorum

$55 \quad 1,00 \quad 5,00 \quad 2,0$

$55 \quad 1,00 \quad 5,00 \quad 2,1$

$55 \quad 1,00 \quad 5,00 \quad 2,2$

Sanat eğitiminin diğer eğitim süreçleri kadar önemli olduğunu düşünüyorum

$55 \quad 1,00 \quad 5,00 \quad 2,1$

Sanat eğitiminin bireylerin kişisel gelişiminde oldukça etkili olduğunu

düşünüyorum

Sanatsal çalışmalara harcadığım zamana üzülmem

$55 \quad 1,00 \quad 5,00 \quad 2,1$

Sanat eğitimi alan bireylerin çevresiyle ilgili sosyal bağının daha güçlü olacağını düşünüyorum

Duygularımı sanatsal çalışmalar yoluyla aktarabilmekten mutluluk duyarım

Her sanat eserinin saygı duyulacak bir tarafı olduğunu düşünüyorum

Sanat eğitimi sadece bir uygulama alanı değil aynı zamanda bilgi kazanma sürecidir

Valid N (listwise)

55

1,9

Tablo 2'ye bakıldığında ise sanat eğitimine yönelik tutum ölçeğine verilen cevapları ve bu cevapların ortalaması görülmektedir. Verilen cevaplardan hareketle en fazla verilen cevabın ortalamasının 2,1 ve 2,0 olduğu görülmekte ve bunun ölçekte olan Karşılığının ise Görsel 
Y. YÜCESOY, B. DEMIR, Okul Öncesi Öğretmen Adaylarının Sanat Ĕ̈itimi ve Görsel

B. BA ĞLAMA, Ü. POLAT Sanatlar Dersine İlişkin Tutumlarının incelenmesi

\& B. ÖZNACAR

Sanatlar eğitimi ölçeğine göre tam tersi olarak "Katılıyorum”, Şeklindedir. Tablodan ulaşılan veriler 1şığında öğrencilerin sanat eğitimine yönelik vermiş oldukları cevapların görsel sanat eğitimine oranla daha olumlu yönde olduğu görülmektedir.

Tablo 3. Okul Öncesi Öğretmen Adaylarının Görsel Sanatlar Dersi ve Sanat Eğitime Yönelik Tutumlarının Ortalamasının Karșılaștırılması

\begin{tabular}{lr}
\hline Dersler & $\mathbf{N}$ \\
\hline Görsel Sanatlar & 1,9 \\
Sanat Eğitimi & 1,9 \\
\hline
\end{tabular}

Tablo 3'e Bakıldığında ise Görsel Sanatlar ve Sanat Eğitimine yönelik öğrencilerin verdikleri cevapların ortalaması görülmektedir Tabloda N kısımında yer alan oranla ölçeklere verilen cevapların ortalamasını göstermektedir. Tabloya göre her iki ders te okul öncesi öğretmen adaylarından 1,9 oran almıştır Görsel Sanatlar Dersine yönelik tutum ölçeğine göre 1,9 öğrencilerin Görsel Sanatlar Dersine yönelik tutumunun olumsuz olduğunu göstermektedir. Sanat eğitimine yönelik tutumlarına bakıldığında ise ortalama olarak 1,9 oran aldığ1 görülmektedir. Öğretmen adaylarının verdiği cevaplar doğrultusunda Sanat eğitimine yönelik tutum ölçeğine göre Sanat Eğitimine yönelik olumlu tutumda olduğunu göstermektedir Görsel sanatlar dersine ve Sanat eğitimine yönelik verilen cevaplar aynı oranda bulunmuş olsa bile ölçeklerin derecelendirmeleri farklı olduğu için bu tablodan hareketle öğretmen adaylarının görsel sanatlar dersine nazaran sanat eğitimi dersini tercih ettikleri ve daha olumlu bir tutuma sahip oldukları söylenebilir.

\section{SONUÇ VE ÖNERILLER}

Okul Öncesi Öğretmenler Adaylarının Sanat Eğitimi ve Görsel Sanatlar Dersine İlişkin Tutumlarının incelendiğinde öğretmen adaylarının sanat eğitimine yönelik tutumların olumlu olduğu görülmüştür. Sanat eğitiminin önemi ve gerekliliğine toplumda önem verilmediği düşünülmüştür. Sanat eğitiminde ve sanat eserlerine gerekli önemin verilmediği düşünülmektedir. Sanat eğitimi aracılığıyla insan sosyal yaşamlarının daha güçlü olabileceği görülmektedir (Ayaydin \& Kurtuldu, 2010). Sanat eğitiminin bireylerin kişisel gelişiminde oldukça etkili olduğu katılımcılar tarafından belirtilmiştir Aynı zamanda bu ölçeğin; Okul öncesi adaylarının, sanat eğitiminin önemine, gerekliliğine olan inancını ve güncel yaşama yansımasına ilişkin düşüncelerini, sanat eğitimi ile ilgili kişisel düşüncelerini, sanat eğitimi süreci ve sonrası ile ilgili yaklaşımlarını, ayrıca sanat eğitiminin bireyin sosyalleşme sürecine katkısı hakkındaki görüşlerini ortaya koyabileceği düşünülmektedir.

Görsel Sanatlar dersine okul öncesi öğretmen adaylarının tutumlarının olumsuz olduğu görülmüştür. Aslan ve Gökdemir (2018) Ortaokul öğrencilerinin görsel sanatlar dersine yönelik tutumlarının çeşitli değişkenler açısından inceledikleri araştırmada ortaokul öğrencilerinin görsel sanatlar eğitimi dersine yönelik tutumlarının bu araştırmanın aksine olumlu bir şekilde olduğu sonucuna ulaşmışlardır .Bu sonuçtan hareketle çalışma gruplarındaki kademelerin düşmesi ile görsel sanatlar eğitimine yönelik tutumlarının olumlu yönde arttığ söylenilebilir.Görsel Sanatlar Dersinde olumlu yönde oluşabilecek tutum değişimini hızlandırabilecek diğer etkenlerde, farklı materyaller, uygulanan teknik, eğitim ortamı, eğitici uygulamalar olabileceği gibi okul ortamı dişında, sosyal ortamı da içine alan geniş bir çevrenin gerekliliği düşünülebilir (Aslantaş, 2013). Bu çevrenin oluşmasında, sadece sanatla bağlantılı değil sosyal iletişimin olabileceği her türlü etkinlik yararlı olabilir (Öztürk \& Dilmaç, 2016). $\mathrm{Bu}$ araştırmada okul öncesi öğretmen adaylarının sanat eğitimine ve görsel sanatlar dersine 
Y. YÜCESOY, B. DEMIR, Okul Öncesi Öğretmen Adaylarının Sanat Eğitimi ve Görsel

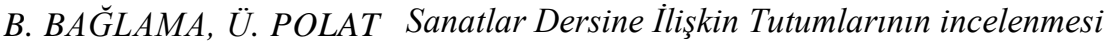

\& B. ÖZNACAR

yönelik tutumları karşılaştırılmıştır. Alanyazın incelendiğinde buna benzer bir karşılaştırmanın yapıldığ 1 bir araştırmaya rastlanmamıştır. Bu noktadan hareketle bu araştırmanın ileriki araştırmalara 1 şı tutacağı düşünülmektedir. Dolayısıyla farklı branşlardan öğretmen adaylarının sanat eğitimi ve görsel sanatlar dersine ilişkin tutumlarının karşılaştırıldığ araştırmaların yapılması önerilmektedir. Bu araştırmanın sonucunda okul öncesi öğretmen adaylarının görsel sanatlar dersine yönelik tutumlarının olumsuz olduğu saptanmıştır. Okul öncesi öğretmen adaylarının bu ders ile ilgili bilgi ve becerilerinin arttırılması adına okul öncesi eğitimi öğretmen yetiştirme programlarında görsel sanatlar dersine ilişkin seçmeli dersleri arttırılması önerilebilir. Öğretmen adaylarının görsel sanatlarla ilgili konferans, kongre ve seminerlere katılmaları teşvik edilmelidir. Okul öncesi öğretmenlerde sanatsal anlayışın oluşabilmesi için, öğretmenlerin hizmet-içi eğitim seminerlerine ve bilimsel etkinlikleri katılma konularında farkındalık oluşturmaları sağlanabilir (Yazıcı, Baydar \&. Pınarcık, 2016). İleriki çalışmalarda farklı araştırma desenleri kullanılarak okul öncesi öğretmen adaylarının sanat eğitimi ve görsel sanatlar dersine yönelik bilgilendirici eğitim programlarının etkililikleri sınanabilir. Sanatın sonuçlarını eğitim ortamlarına entegre etme konusunda yetkin öğretmenler yetiştirmek için öğretmen yetiştirme programlarında sanat öğretimi üzerine daha fazla ders olmalidir (Allahverdiyev, Yucesoy \& Baglama, 2017).

\section{KAYNAKÇA}

Akyüz, Y. (1978). Türkiye'de öğretmenin öğretmen ve meslek imaj1. Ankara Üniversitesi Ĕ̆itim Bilimleri Fakültesi Dergisi, 11(1), http://dergiler.ankara.edu.tr/dergiler/40/500/5972.pdf.

Allahverdiyev, M., Yucesoy, Y., \& Baglama, B. (2017). An overview of arts education and reflections on special education. International Journal of Educational Sciences, 19(2-3), 127-135.

Aslan, S., \& Gökdemir, M. A. (2018). Ortaokul öğrencilerinin görsel sanatlar dersine yönelik tutumlarının çeşitli değişkenler açısından incelenmesi. SDU International Journal of Educational Studies, 5(2), 53-63.

Aslantaş, S. (2013). İlköğretim 4. sınıf görsel sanatlar dersinde disiplinlerarası yaklaşıma göre yapılan öğretimin öğrencilerin derse ilişskin tutumlarına etkisi. Gaziosmanpaşa Bilimsel Araştırma Dergisi, 2, 1-13.

Aslantaş, S. (2014). Görsel sanatlar dersine yönelik tutum ölçeği geliştirilmesi. Uluslararası Türk Eğitim Bilimleri Dergisi, 2014(2), 185-196.

Ayaydın, A., \& Kurtuldu, M. K. (2010). Sanat eğitimine yönelik tutum ölçeğinin geliştirilmesi. Fırat Üniversitesi Sosyal Bilimler Dergisi, 20(2). 201-209.

Aykanat, E. (2018). Okul öncesi ögrretmenlerinin sanat eğitimine yönelik tutumlarını belirlemek üzere ölçek geliştirme çalışması. [Yayınlanmamış yüksek lisans tezi, Başkent Üniversitesi Eğitim Bilimleri Enstitüsü]. Yök Tez Veri Tabanı.

Başbuğ, F., \& Başbuğ, Z. (2016). Görsel sanatlar eğitimi üzerine notlar. Akdeniz Sanat Dergisi, 9(18). 74-98.

Bicen, H., \& Demır, B. (2020). A content analysis on articles using augmented reality technology and infographic in education. Postmodern Openings/Deschideri Postmoderne, 11, 33-44.

Bilgin Aksu, M. ve Demirtaş, H. (2006). Öğretmen adaylarının okul deneyimi II dersine ilişkin görüşleri (İnönü Üniversitesi Eğitim Fakültesi örneği). İnönü Üniversitesi Eğitim Fakültesi Dergisi, 7(1), 3-21.

Bozdoğan, A. E., \& Altunçekiç, A. (2007). Fen bilgisi öğretmen adaylarının 5e öğretim modelinin kullanılabilirliği hakkındaki görüşleri. Kastamonu Eğitim Dergisi. 579-590.

Büyüköztürk, Ş., Çakmak, E. K., Akgün, Ö. E., Karadeniz, Ş., \& Demirel, F. (2017). Bilimsel araştırma yöntemleri. Pegem Atı İndeksi.

California Department of Education, (2004). Visual and performing arts framework. http://www.cde.ca.gov/ci/cr/cf/documents/vpaframewrk.pdf 
Y. YÜCESOY, B. DEMIR, Okul Öncesi Öğretmen Adaylarının Sanat Eğitimi ve Görsel

B. BA $\breve{G} L A M A, \ddot{U}$. POLAT Sanatlar Dersine İlişkin Tutumlarının incelenmesi

\& B. ÖZNACAR

Çoklar, A.N. ve Şahin, Y.L. (2008). Assesments of ceit department students related to computer hardware course. 8th International Educational Technology Conference. Eskişehir: Anadolu University, http://ietc2008.home.anadolu.edu.tr/ietc2008/14.doc

Demir, B. (2020). Evaluation of social studies teaching textbooks. International Journal of Learning and Teaching, 12(1), 17-29.

Drew, W.F. (1995). Recycled materials: Tools for creative thinking. Scholastic Early Childhood Today, 9(5), 3643.

Erdemir, N., \& Kandır, A. (2002). Erken çocukluk eğitiminde yaratıcı sanat etkinlikleri. Erken Çocukluk Gelişsimi ve Eğitimi Sempozyumu. Kök Yayıncılık.

Ersoy, F. (2006). Öğretmen adaylarının gelişim dosyasına dayalı değerlendirmeye ilişkin görüşleri. İlköğretim Online, 5(1), 85-95, http://ilkogretim-online.org.tr

Ertürk, M. (2011). İlköğretim II. kademe görsel sanatlar eğitimi dersi öğretim programının öğretmen görüşlerine göre değerlendirilmesi. Anadolu Üniversitesi Ĕ̆itim Bilimleri Enstitüsü Dergisi, 3(1). 78-94.

Faraday, A. (1990). Young children and art: the importance of critical studies. Early Child Development and Care, 59(1), 73-86.

Gandini, L., \& Kaminsky, I. (2003), Remida, the creative recycling center in Reggio Emilia: An interview with Elena Giacopini, Graziella Brighenli, Arturo Bertoldi and Alba Ferrari. Innovations in Early Education. 12(3), 1-13.

Gedikoğlu, T. (2005). Avrupa birliği sürecinde Türk eğitim sistemi: Sorunlar ve çözüm önerileri. Mersin Üniversitesi Eğitim Fakültesi Dergisi, 1(1).

Gökaydın, N. (2002). Temel sanat ĕgitimi. MEB Yayınları.

Karamustafaoğlu, S., Üstün, A., \& Kandaz, U. (2004, Temmuz). Okul öncesi öğretmen adaylarının fen ve doğa etkinliklerini uygulayabilme düzeylerinin belirlenmesi. XIII. Ulusal Eğitim Bilimleri Kurultayl,. İnönü Üniversitesi Eğitim Fakültesi, Malatya.

McKean, B. (2001). Concerns and considerations for teacher development in the arts. Arts Education Policy Review, 102(4), 27-32.

Millî Eğitim Bakanlığı, (2006). İlköğretim Sanat Etkinlikleri Dersi Programı ve Kılavuzu. Ankara: MEB Yayınlar1.

Nacak, A., \& Yücesoy, Y. (2020). Art education for communication in the society: a content analysis. Revista Tempos e Espaços em Educação, 13(32), 1-15.

Nacak, A., Bağlama, B., \& Demir, B. (2020). Teacher candidate views on the use of youtube for educational purposes. Online Journal of Communication and Media Technologies, 10(2), e202003.

Newton, L. D., \& Newton, D. P. (2005). Thinking about art: Could elementary textbooks serve as models of practice to help new teachers and non-specialists support reasoning in art? International Journal of Art \& Design Education, 24(3), 315-324.

Özsoy, V. (2006). Görsel sanatlar eğitiminde uygulamalar. Görsel Sanatlar Eğitimi Derneği Yayınları.

Öztürk, D., \& Dilmaç, O. (2016). Görsel sanatlar öğretmenlerinin değerler eğitimine ilişkin tutumlarının bazı değişkenler açısından incelenmesi. Bayburt Ĕgitim Fakültesi Dergisi, 11(1), 224-237

Öztürk, Ş. \& Darıca, N. (2003). Çocuk gelişimi ve okulöncesi eğitimi öğretmenliği, anaokulu öğretmenliği ve okulöncesi öğretmenliği lisans programlarında yer alan yaratıcılıkla ilgili derslere ilişkin görüşler. Ĕgitim Araştırmalarl, 4(13), 10-21.

Pehlivan, H. (2006). İlköğretim sınıf öğretmeni adaylarının sanat eğitiminde internet sitesi oluşturmaları ve görüşleri. Illköğretim Online, 5(2), 35-47.

Polat, Ü, Kaysılı, A, Aydın, Ş. (2015). Öğretmen Adaylarının Eğitimsel, Toplumsal ve Siyasal Beklentileri Üzerine Bir Araştırma. Cumhuriyet Uluslararası Eğitim Dergisi, 4(2), 1-14. https://doi:10.30703/cije.321365

Sahasrabudhe, P. (2006). Design for learning through the arts. International Journal of Education Through Art, 2(2), 77-92. 
Y. YÜCESOY, B. DEMIR, Okul Öncesi Öğretmen Adaylarının Sanat Eğitimi ve Görsel

B. BA ĞLAMA, Ü. POLAT Sanatlar Dersine İlişkin Tutumlarının incelenmesi

\& B. ÖZNACAR

Schiller, W. (2005). Children's perceptions of live arts performances: a longitudinal study. Early Child Development and Care, 176(6), 543-552.

Székely, G. (2001). Handmade art. Art and Activities, 38-42.

Szyba, C.M. (1999). Why do some teachers resist offering appropriate, open-ended art activities for young children? Young Children, 54(1), 16-20.

Şahin, E., \& Özkılıç, R. (2005). Okul öncesi eğitimi öğretmen adaylarının uygulama dersleri için hazırlanan uygulama kılavuzu hakkındaki görüşleri. Gazi Üniversitesi Gazi Eğitim Fakültesi Dergisi, 25(2), 115133.

Turgut, M., Yılmaz, S. \& Firuzan, A. R. (2008). Okul deneyimi uygulama sürecinin değerlendirilmesi üzerine bir araştırma. Bilim, Eğitim ve Düşünce Dergisi, 8(2), 1-26.

Yazıcı, E., Baydar, I., Y. \&. Pınarcık. Ö. (2016). Okul öncesi öğretmenlerinin sanata ilişkin görüşlerinin incelenmesi. EUluslararası Eğitim Araştırmaları Dergisi, 7(3), 74-88. https://doi:10.19160/e-ijer.80596

Yelken, T. (2006). İlköğretim sınıf öğretmeni adaylarının sosyal bilgiler dersinde tamamlayıcı değerlendirme yaklaşımları konusundaki görüşleri. Sosyal Bilimler Arastırmaları Dergisi, 2, 58-75.

Yelken, T. Y., \& Alici, D. (2008). Öğretmen adaylarının hazırladıkları performansa dayalı değerlendirme materyallerine ilişkin görüşlerinin ve değerlendirmelerinin incelenmesi. Journal of Qafqaz University, 24. 222-235.

Yıldırım, A., \& Şimşek, H. (2006). Sosyal bilimlerde nitel araştırma yöntemleri (6. Baskı). Seçkin Yayıncılık.

Yücesoy, Y., Bağlama, B., \& Tüzel, M. (2020). Art education, therapy interventions and school management in autism. Revista Romaneasca pentru Educatie Multidimensionala, 12(1), 334-349. https://doi:10.18662/rrem/217

Yücesoy, Y., Demir, B., Bağlama, B., Baştaş, M., \& Öznacar, B. (2020). Secondary education teachers and school administrators' views on positive organizational climate. Near East University Online Journal of Education, 3(1), 12-21. 


\section{EXTENDED ABSTRACT}

\section{Investigation of Preschool Teacher Canidates' Attitudes Towards Art Education and Visual Arts Course}

Art; It is a special area where individuals have the opportunity to express themselves emotionally by using techniques and methods unique to them. Individuals who have received art education are expected to be able to evaluate the awareness of the art objects in their environment and the objects according to the art theories. Art education; It is the discipline of education that an individual performs through art for his physical, emotional, perceptual and mental development. It is an effort to mature the talent and creativity power of the individual, to develop versatile thinking and aesthetic tastes. In other words, art education, starting from childhood, cultivates all individuals culturally; To develop intuition, reasoning, imagination and skill in the right way, to build a multi and diverse literacy step by step, and at the same time to teach various ways of perception and thought, aiming with skill training, to teach individuals the senses of seeing, hearing and similar through art, Supporting their abilities, enabling them to understand the difference between looking and seeing and helping to reveal their creative power. The preschool period is the period in which children's physical, mental, emotional and social development and learning are at their highest level, and at the same time, the child's personality, talent, creativity and imagination are shaped. During this period, our teachers have a great responsibility. It is important for teacher candidates to provide qualified artistic experiences in their classrooms and to be able to use art both as a purpose and as a tool in order to develop their artistic awareness and increase their sensitivity towards art in their professional lives. With this research, it is aimed to examine Preschool Teacher Candidates' Attitudes towards Art Education and Visual Arts Lesson. The study group of the research consists of 55 Preschool Teacher candidates who are studying at universities in the 2019-2020 academic year and who participate on a voluntary basis. Within the scope of the research, the Attitude Towards Art Education and Attitude Towards the Visual Arts Course scale was used to determine the attitudes of pre-school teacher candidates towards Visual Arts Course and Art Education. The data were analyzed with SPSS 17 statistical program and validity tests were conducted. Pearson Correlation was used in the analysis of the data. Results were presented in summary tables consisting of frequency (n) distribution, mean and standard deviation. The significance level was taken as $5 \%(\mathrm{p}=0.05)$ in all analyzes. As a result of the research; preschool teachers try to use definitions that cover the concept of art; they know various branches of art and the subbranches of these branches of art, mostly visual arts; that the majority of teachers are engaged in or want to deal with a branch of art; It has been found that striving and willingness to deal with them are due to various reasons. Through art education, unknown artworks in different countries are learned and the importance of these works by students is considered. It was stated by the participants that art education is very effective in the personal development of individuals. Their attitudes towards art education will be revealed more easily. At the same time, this scale; Preschool candidates, It is thought that it can reveal its belief in the importance and necessity of art education and its reflection on contemporary life, personal thoughts about art education, approaches about the art education process and its aftermath, as well as views on the contribution of art education to the individual's socialization process. In order to increase the knowledge and skills of pre-school teacher candidates regarding this course, it may be suggested to increase the elective courses related to the visual arts course in pre-school education teacher training programs. Teacher candidates should be encouraged to attend conferences, congresses and seminars on visual arts. In order to create artistic understanding in preschool teachers, it can be ensured that teachers raise awareness about participating in in- 
Y. YÜCESOY, B. DEMIR, Okul Öncesi Öğretmen Adaylarının Sanat Ĕ̈itimi ve Görsel B. BA $\breve{G} L A M A, \ddot{U}$. POLAT Sanatlar Dersine İlişkin Tutumlarının incelenmesi \& B. ÖZNACAR

service training seminars and scientific activities. In addition, it has been determined that all of the teachers expressed their opinion.

\section{(c) (1) @)(}

"International Journal of New Approaches in Social Studies - IJONASS" is licensed under a Creative Commons Attribution-NonCommercial-ShareAlike 4.0 International License. 